\title{
SYSTEMATIC RELATIONSHIPS BETWEEN INDUSTRIAL LINKAGES AND THE AGGLOMERATION OF MANUFACTURING INDUSTRIES
}

\author{
Charles Richter
}

University of North Carolina

A recent empirical study has identified industrial linkages as an agglomeration economy. 1 The purpose of the present paper is to focus attention upon more specific relationships between industrial linkages and the agglomeration of manufacturing industries.

This study consists of posing and testing four hypotheses pertaining to relationships between linkages and agglomeration. The first hypothesis examines whether strong linkages between pairs of manufacturing industries are more important locational forces than weaker linkages. Supply and demand linkages 2 are then evaluated in two respects. A test is conducted to determine whether or not supply and demand linkages are equally potent locational influences on all of the manufacturing sectors considered together. Another test is devised to determine if primary resource users tend to be material oriented while producers in the latter stages of manufacturing processes are demand oriented. The final hypothesis considers whether the final demand sales of manufacturing sectors influence the dispersions of their employment proportions located in large metropolitan areas.

In order to test these hypotheses, cross-sectional employment data ${ }^{3}$ were collected for each of 51 manufacturing sectors in each of 57 metropolitan areas. ${ }^{4}$ The 51 sectors are composed of the same combinations of two-, three-, and fourdigit SIC categories as those found in the 1958 input-output table.5 Industrial linkages are defined on the basis of the sizes of input-output coefficients. If there are $n$ sectors in an input-output table, Leontief considered there to be a special relationship between two sectors if one sells one n'th or more of its ourput to the other or if one purchases one $n$ 'th or more of its inputs from the other. 6 The former is a demand linkage, the latter a supply linkage. Since there are a total of 82 sectors in the 1958 input-output table, two sectors are linked if one sells at least 1.2 per cent of its output to the other or if one buys at least 1.2 per cent of its input from the other.

The 51 by 57 matrix of employment figures is used to determine which sector pairs locate in geographic proximity. This is accomplished by computing 2550 correlation coefficients between the sector pairs. 7 Sector pairs whose corresponding correlation coefficients are significantly greater then zero at the .10 level of significance are defined as being geographically associated. In my earlier article, it was found that the manufacturing sectors which are linked are more likely to be geographically associated than those which are not linked.

The measure of geographic association just established serves as a convenient tool to examine some agglomerative implications of industrial linkages. This measure is frequently employed in the remainder of this paper to assist in testing the four previously posed hypotheses.

\section{Strong Linkages are More Important than Weak Ones}

The first hypothesis is that strongly linked sectors are more likely to locate close together than those which are weakly linked. By finding the percentages of geographic associations accompanying linkages of varying strengths, the hypothesis can be accepted or rejected. The 517 linkages among manufacturing sectors are classified by their strengths in Table 1 . Since it was difficult to decide upon a method of classifying linkages by their strengths, a few groupings were attempted. All yielded similar results; the percentages of geographic associations accompanying stronger linkages consistently exceeded the 
percentages accompanying weaker linkages. This can be seen by examining Table 1 . If another category were inserted in the table for linkages representing at least 15 per cent of intersectoral transactions, 43 per cent of these could be seen to be accompanied by geographic associations. It can be concluded that the data support the hypothesis as stated. As might be expected, stronger linkages appear. to be more potent locational forces on sector pairs than weaker linkages.

TABLE 1

NUMBER AND PERCENTAGE OF ASSOCIATED LINKAGES BY LINKAGE STRENGTH GROUPS

\section{Strength of linkage (percentage of inputs or outputs)}

\section{2 to 2.9}

3.0 to 7.4

7.5 and over

\author{
Number \\ of \\ 1inkages
}

307

149

61

\begin{abstract}
Number of Associated linkages
\end{abstract}

71

41

19

\author{
Per cent of \\ associated \\ linkages
}

23.1

27.4

31.1

\section{Supply and Demand Linkages are Equally Important}

The second hypothesis states that interindustry supply linkages and demand linkages are equally important locational influences on the 51 manufacturing sectors when all of them are considered together. More specifically, an attempt is made to determine whether sector pairs joined by supply linkages are more, less, or equally likely to be located in geographic proximity as sector pairs connected by demand linkages.

The data confirm the stated hypothesis. As seen in Table 2, 58 of the 230 demand linkages and 73 of the 286 supply linkages are accompanied by geographic associations. 8 These figures represent 25.2 per cent of the demand linkages and 25.5 per cent of the supply linkages. Since the two percentages differ by so little, less than one percentage point, neither type of linkage appears to be a more potent locational force than the other. ${ }^{9}$ Therefore, the hypothesis is confirmed. Note that the hypothesis was stated for all sectors considered together; as seen below, it does not hold when the sectors are grouped according to their uses of primary resources.

\section{First Stage Resource Users are Supply Oriented; Third Stage Users are Demand Oriented}

The third hypothesis is that earlier stages of manufacturing are generally material oriented while latter stages tend to be market oriented. Edgar Hoover implied that this hypothesis would be accepted after noting that primary industries usually handle bulky weight-losing raw materials, and industries comprising the more advanced stages of manufacturing processes are confronted by discriminatory freight rates against their finished goods. 10

If the hypothesis is true, it is likely that more group III sectors (those to which primary resources have the least direct importance) are located inside urban areas than group I sectors (primary resource users).11 
DEMAND LINKAGES, SUPPLY LINKAGES, GEOGRAPHIC ASSOCIATIONS, AND PROPORTIONS OF EMPLOYEES IN THE 57 METROPOLITAN AREAS FOR THE 51 MANUFACTURING SECTORS

Total \begin{tabular}{c}
$\begin{array}{c}\text { Geographi- } \\
\text { cally } \\
\text { associated }\end{array}$ \\
\hline
\end{tabular}

Food \& kindred products Tobacco

Broad \& narrow fabrics,

yarn \& thread mills

Miscellaneous textile

goods \& floor coverings

Appare1

Miscellaneous fabricated textile products

Lumber \& wocd products,

$\in x c e p t$ containers

Wooden containers

Hoissehold furniture

other furniture \& fixtures

0
0
5
8
0

Paper \& allied products

$$
\text { except containers }
$$

Paperboard containers \&

$$
\text { boxes }
$$

Printing \& publishing

Chemical \& selected chemical products

Plastics \& synthetic

materials
Demand 1inkages

0
0

5

8

Supp1y 1inkages

\begin{tabular}{cc}
$\begin{array}{c}\text { Geographi- } \\
\text { cally } \\
\text { Total }\end{array} \quad$ associated \\
\hline
\end{tabular}

2

1

2

1

0

1

8

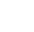

5

13
0

11

11

11
Geographic assoclations

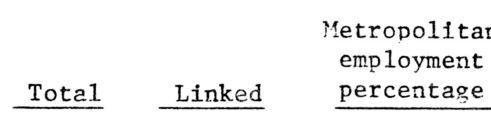

52.14

36.35

26.03

51.79

56.95

77.61

14.30

32.37

43.88

70.65

43.30

72.17

72.52

58.22

35.98 
TABLE 2 contd.

\section{Demand linkages}

Sector

Tota1

Drugs, cleaning, \& toilet preparations

Paints \& allied products

Petroleum rofining \& rolated industries

Rubber \& miscellaneous

$$
\text { plastics products }
$$

Leather tanning \& indus-

trial leather products 3

Footwear \& other 1eather products

Glass \& glass products

Stone \& clay products

Primary iron and steel

primary nonferrous metals

Metal containers

Heating, plumbing \&

strictural metal

products

tampings, screw machine

protucts \& bolts

other fajricated metal

products

Engines \& turbines cally
Supply linkages Geographic lissociations

Geographiassociated

$\underline{\text { Total }}$

Geographi-
cally
associated

Tota1

Linked

Metropolitan employment percentage

81.40

88.89

65.07

79.73

54.95

54.61

61.81

44.43

67.07

68.18

86.07

62.79

76.77

74.87

67.24 
TABLE 2 Cont.

\section{Demand 1inkages}

\section{Sector}

Tota1

Geographically

associated

Farm machinery

$$
\text { equipmen } t
$$

Construction, mining, \&

$$
\text { oil field }
$$

Materials handling

machinery \& equipment

Metalworking machinery \&

equipment

Special industry machinery

$$
\& \text { equipment }
$$

Supp1y 1inkages

Geographically

Total
Total
Geographic associations
Metropolitan employment

percentage
General industrial machinery $\&$ equipment

Machine shop products

Office, computing \& accounting machines

Service industry machines Electric industrial equipment \& apparatus

Electric 1ighting \& wiring equipment

Radio, television \& communication equipment 
TABLE 2 Cont.

Sector

Motor vehicles \& equipment

Aircraft \& parts

Other transportation

equipment

Scientific \& controlling

instruments

Optical, opthalmic \&

photographic equipment

Miscellaneous manufacturing

SUMS

230
Demand linkages

Supply 1inkages

Geographi-

cally

associated$$
\text { cally }
$$

associated

$\underline{\text { Total }}$

0

0

0

4

2

1

2

\begin{tabular}{rr}
0 & 5 \\
0 & 6 \\
0 & 9 \\
1 & 10 \\
0 & 6 \\
0 & 10 \\
\hline 58 &
\end{tabular}

Geographic associations

Metropolitan

employment

$\underline{\text { Total } \quad \text { Linked }}$

percen

77.32

84.91

60.41

76.65

94.78

76.88 
TABLE 3

PERONTAGES GF EMP OYEES OF EACH SECTOR GROUP LOCATEI) IN T'HE 57 METROPOLITAN AREAS

$\begin{array}{lccc} & \text { Group I } & \text { Group II } & \text { Group III } \\ \text { Group A } & 51.2 & 61.3 & 76.6 \\ \text { Group B } & 44.0 & 64.9 & 64.9 \\ \text { Weighted nean cf A. and B } & 46.7 & 63.2 & 66.9\end{array}$

a. See the appendix for sector groupings

By examining Tabje 3, it is seen that the advanced stages of manufacturing are more concentrated in the 57 metropolitan areas thin the earlier stages. About 46.7 per cent of the group I employees work in these areas as contrasted with a nuch higher percintare, 71.4 per cent, of the group III workers. The percentage of group II's employees (second stage resourch users) working in the metropolitan aruas 1ies between the other two percentages. An analysis of variance test, based on the metropolitan area employment proportions in Table 2 , shows that the means preserted in Table 3 are significantly different.

\section{TABLE 4}

SUMMARY TAHLE FOR ANALYSIS OF YARTANCE

\section{$\underline{\text { Varjations }}$}

Between groups

Within groups;

\section{Degrees of freedom}

2

48

\section{Sum of squares}

$$
12,165
$$

2, 970

\section{Variance}

6,082

62

A summary table for the anelysis of variance appears in Table 4. The ratio of the variance between groups to the variance within groups of 98.4 is considerably greater than 5.08, the critjcal value of F-statistic at the .01 level of significiance with tho degrees of freedom ir the ntmerator and 48 in the denominator. 12 Therefore, the noce advanced stages of manufacturing prccesses are the most likely to locate ir metropolitan areas. This conclusion offers some supprert to the first part of the hypothesis that earlier stages of production processes art: material oriented and the latter stages rarket: critnted.

The hypothesis receives additjont support from the cata presented in Table 5. These data indicate that a supply iinkage is more likely to have a locational influence on a group I sector, while a demand jinkage is more likely to have a locational influence un a group II sector. For the group I sector:, one-halt of the supply linkages are accompanitd by geographic associations, compared to 27.0 per cent fox the demari linkages. Sinc hes linkages do not include those with extractive indusiries, the data lend little support to a hypothesis stiting that sfctors using pitary resources are oniented toward extractive industries. Nevertheless, group I marufacturers to appear to be clearly supply 
NUMBERS AND PERCENTAGES OF LINKAGES ACCOMPANIED BY GEOGRAPHIC ASSOCIATIONS FOR RESOURCE-USE SECTOR GROUPS

\begin{tabular}{|c|c|c|c|c|c|c|}
\hline \multicolumn{4}{|c|}{ Demand Linkages } & \multicolumn{3}{|c|}{ Supply Linkages } \\
\hline Group & $\begin{array}{l}\text { No. of } \\
\text { linkages }\end{array}$ & $\begin{array}{l}\text { Number of } \\
\text { associated } \\
\text { linkages }\end{array}$ & Percent & $\begin{array}{l}\text { No. of } \\
\text { linkages }\end{array}$ & $\begin{array}{c}\text { Number of } \\
\text { associated } \\
\text { linkages }\end{array}$ & Percent \\
\hline I & 37 & 10 & 27.0 & 16 & 8 & 50.0 \\
\hline II & 125 & 31 & 24.8 & 199 & 52 & 26.1 \\
\hline III & 68 & 16 & 23.5 & 71 & 13 & 18.3 \\
\hline
\end{tabular}

oriented. As one progresses from group I to group II sectors, the importance of both demand and supply linkages drops, but demand linkages acquire more relative importance than supply linkages for the sectors to whichprimary resources have the least direct importance. The group III sectors has 23.5 percent of their demand linkages and 18.3 percent of their supply linkages accompanied by geographic associations.

In summarizing the findings of this section, it is seen that the data do support the stated hypothesis. The primary resource users may prefer locations outside the metropolitan areas in order that they can be near their sources of supply. On the other hand, latter stage manufacturers may find urban locations profitable. Within urban areas there is certainly a large source of demand for finished goods which probably attracts those manufacturers who produce goods for the final demand sector. Further support for the hypothesis is achieved by noting that the locational decision of earlier stage manufacturers appears to be more strongly influenced by supply linkages to other manufacturers while latter stage producers are more oriented toward their markets. As would be expected, primary resource users are material oriented and latter stage producers are market oriented.

\section{Final Demand Sales and Employment Dispersions}

The last of the four hypotheses concerns the distributions of sector employment proportions in the 57 metropolitan areas. One column of Table 2 contains the proportion of each sector's employees working inside the 57 metropolitan areas. The hypothesis states that the dispersion of employment proportions for industries which do not sell large proportions of their output to final demand equals the dispersion of the employment proportions of industries which sell larger proportions of their output to the final demand sector. 13 This hypothesis is expected to be discredited with the former dispersion exceeding the latter. It is likely that the industries which sell larger proportions of their output to the final demand sector locate near the populace to whom they sell much of their output. Consequently, these employment figures may be sensitive to the populations of the sampled metropolitan areas. On the contrary, sectors which are not linked to the final demand sector would supposedly be less sensitive to population. Accordingly, some of these sectors may employ most of their labor forces outside the metropolitan areas while other of these manufacturers may be strongly attracted toward the skilled labor forces frequently found in large cities.

As expected, the hypothesis is discredited. The sectors which are strongly linked to the final demand sector have a mean of 64.6 per cent of their employees inside the 57 metropolitan areas. The variance about this mean is 227 percentage points. Those sectors which are not strongly linked to final demand have a mean of 61.7 percent of their employees in the metropolitan areas and a variance of 345 percentage points about this mean. The ratio of the variance of the latter sectors to that of the former is 1.52 . Thus the employment dispersions of the sectors which do not sell much of their output to the final demand sector exceeds that of the sectors which sell larger proportions of their output to the final demand sector. 
Conclusions

In this paper, relationships between industrial linkages and the agglomeration of manufacturing industries were examined. It was found that strong linkages are more imporatnt locational forces than weak linkages. Supply and demand linkages are equally potent locational forces on all manufacturing sectors considered together. However, supply linkages are relatively more important locational influences on the industries in the earlier stages of production processes; demand linkages are more important for the latter stage producers. Finally, it was found that the final demand sales of manufacturing sectors influence the dispersions of these sectors' employment proportions in metropolitan areas.

\section{APPENDIX}

\section{SECTOR GROUPS}

In order to evaluate third and fourth hypothesis posed in this paper, it is necessary to combine the 51 manufacturing sectors into a smaller number of groups. A two-way classification system is used for the 51 sectors. The first classification refers to the importance of primary resources, and the second is by the importance of sales to the final demand sector.

The classification of sectors by resource use is similar to a classification techniques used by Perloff, Dunn, Lampard, and Muth. 1 Each sector was placed in one of three groups. The first group (group I) includes first stage resource users. The second group (group II) includes second stage resource users, and the third (group III) is composed of sectors to which primary resources are of the least direct significance. If a sector spends at least 7.5 percent of its input dollar on the products of extractive industries, the sector is classified as a group I sector. The figure of 7.5 percent was chosen in order that most of the industries which are usually considered to be primary manufacturers would be included among the first stage resource users. A lower figure would result in too many sectors being placed in group II if the same percentage is used to separate the group II and III sectors as is used to separate the groups I and II sectors. By arbitrarily retaining the 7.5 percentage figures, the second stage resource users are defined such that they purchase at least 7.5 per cent of their inputs (in dollar terms) from the first stage resource users. The remaining sectors (group III) which are not included among those in the first two groups are the sectors to which primary resources have the most indirect significance.

The above three groups are subdivided depending on the proportion of each sector's output which is destined for final demand. If a sector sells at least 7.5 per cent of its output to the final demand sector, it is defined as strongly linked to final demand. Sectors are placed in subgroup A of the resource use groups if they are strongly linked to final demand; those in subgroup $B$ are not strongly linked to the final demand sector.

The classifications of the sectors into six groups are found in the table included in this appendix. These data were obtained from the 1958 input-output table. Group I-A includes the first stage resource users whose sales to final demand are important. The first stage resource users which are not linked to final demand are in group I-B. Second stage resource users are classified in groups II-A or II-B depending on their sales to final demand. Of the sectors to which primary resources have the most indirect importance, those in group III-A are strongly linked to final demand while those in group III-B are not. There 
are three sectors in group I-A, five in I-B, thirteen in II-A, fifteen in II-B, seven in III $-\Lambda$, and eight in III-B. Thus eight sectors are first stage resource users, 28 are second stage resource users, and to the other 15 primary resources are of the most indirect importance. Twenty-three of the sectors are strongly linked to final demand, twenty-eight are not.

SECTOR GROUPS BY RESOURCE USE AND SALES TO FINAL DEMAND

\section{Sector}

Food \& kindred products

Tobacco manufactures

Broad \& narrow fabrics, yarn \& thread mills

Miscellaneous textile goods \& floor coverings Appare1

Miscellaneous fabricated textile products

Lumber \& wood products, except containers

Wooden containers

Household furniture

other furniture \& fixtures

Paper \& allied products, except containers

Paperboard containers $\varepsilon_{t}$ boxes

Printing \& publishing

Chemicals \& selected chemical products

Plastics \& synthetic naterials

Drugs, cleaning \& toilet preparations

Paints \& allied products

Petroleum refining \& related industries

Rubber \& miscellaneous plastics products

Leather tanning $\&$ industrial leather products

Footwear \& other leather products

Glass \& glass products

Stone \& clay products

Primery iron \& stee 1

Primary nonferrous metals

\begin{tabular}{|c|c|c|c|}
\hline Group & $\begin{array}{l}\text { Input } \\
\text { per cent } \\
\text { from } \\
\text { resource } \\
\text { extractors } \\
\end{array}$ & $\begin{array}{l}\text { Input } \\
\text { per cent } \\
\text { from } \\
\text { stage I } \\
\text { sectors }\end{array}$ & $\begin{array}{c}\text { Output } \\
\text { per cent } \\
\text { to } \\
\text { final } \\
\text { demand }\end{array}$ \\
\hline I-A & 34.3 & 17.2 & 70.6 \\
\hline I-A & 18.3 & 19.9 & 71.3 \\
\hline$I-B$ & 11.9 & 35.2 & 6.6 \\
\hline II-A & 2.8 & 1.6 .9 & 29.7 \\
\hline II-A & 1.0 & 27.4 & 78.7 \\
\hline II-A & --- & 44.2 & 48.1 \\
\hline$I-B$ & 11.8 & 29.8 & 1.8 \\
\hline II-B & -- & 41.8 & 0.1 \\
\hline II-A & 0.1 & 22.7 & 74.9 \\
\hline II-A & --- & 17.2 & 17.1 \\
\hline IT-A & 1.2 & 9.2 & 8.2 \\
\hline III-B & --- & 0.8 & 1.0 \\
\hline III-A & ---- & 0.2 & 20.7 \\
\hline II-B & 4.9 & 9.0 & 3.8 \\
\hline III-B & 0.6 & 1.9 & 0.2 \\
\hline IJI $-\mathrm{A}$ & 0.2 & 4.2 & 58.6 \\
\hline III-B & --- & 5.7 & 0.9 \\
\hline I-A & 52.0 & 7.2 & 42.4 \\
\hline III-A & 0.3 & 3.2 & 20.1 \\
\hline [I] $-B$ & 0.4 & 1.6 & ---- \\
\hline III- $\Lambda$ & $\cdots-$ & 3.7 & 83.7 \\
\hline III-B & 1.3 & 4.9 & 5.9 \\
\hline I-B & 7.9 & 14.0 & 2.8 \\
\hline $\mathrm{T}-\mathrm{B}$ & 8.4 & 26.8 & 0.1 \\
\hline$I-B$ & 8.3 & 32.7 & 0.1 \\
\hline
\end{tabular}




\section{Sector}

Metal containers

Heating, plumbing \&

structural metal products

Stampings, screw machine products \& bolts

Other fabricated metal products

Engines \& turbines

Farm machinery \& equipment

Construction, mining \& oil field machinery

Materials handling machinery \& equipment

Metalworking machinery $\&$ equipment

Special industrial machinery \& equipment

General industrial machinery $\&$ equipment

Machine shop products

Office, computing \& accounting machines

Service industry machines

Electric industrial equipment $\&$ apparatus

Household appliances

Electric lighting \& wiring equipment

Radio, television \& communication equipment

Electronic components

$$
\& \text { accessories }
$$

Miscellaneous electrical machinery \& supplies

Motor vehicles \& equipment

Aircraft \& parts

Other transportation equipment

Scientific \& controlling instruments Optical, ophthalmic \& photographic equipment

Miscellaneous manufacturing

\section{Group}

II-B

II-B

II-B

II-B

II-B

II-B

II-B

II-B

II-B

II-B

II-B

II-B

III-B

II-A

II-B

II-A

II-A

III-A

III-B

II-A

II-A

III-B

II-A

III-A

III-A

II-A

$$
\text { Input }
$$
per cent

from

resource

extractors

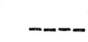

Output per cent to final demand

45.4

32.5

0.9

28.3

6.8

28.0

6.5

0.1

14.5

5.8

1.0

0.2

16.3

0.7

12.8

4.5

11.8

0.9

15.0

2.0

15.0

18.3

0.1

\section{3}

4.5

13.1

6.5

11.9

14.1

0.4

13.2

67.2

12.9

14.0

3.5

23.5

7.4

5.6

14.4

18.8

10.4

41.1

6.8

0.2

17.2

20.2

7.4

12.1

5.3

29.8

0.2

0.2

11.3

48.9 


\section{FOOTNOTES}

${ }^{1}$ Charles Richter, "The Impact of Industrial Linkages on Geographic Association," Journal of Regional Science 9, No. 1.

${ }^{2}$ Sector A is connected to sector B via a demand linkage if A sells a large proportion of its output to B. Conversely, A is linked to B via a supply linkage if A purchases a large proportion of its inputs from $B$. These definitions are made more specific later.

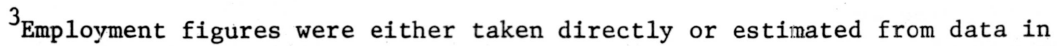
the U. S. Bureau of the Census, U. S. Census of Manufactures: 195, Volumes III and IV, (Washington, D. C.: U. S. Government Printing Office, 1963).

${ }^{4}$ Fifty-four of the metropolitan areas are large SMSA's and the remaining three are whole states. A more complete description of the data and sampled regions is found in Richter, op. cit.

${ }^{5}$ Morris R. Goldman, M. L. Marimont, and B. L. Vaccara, "The Interindustry Structure of the United States," Survey of Current Business 44 (November 1964): 10-29.

6Wassily Leontief, "The Structure of the U. S. Economy," Scientific American 212 (April 1965): 25-35.

7To avoid upward biases the employment figures were deflated by total manufacturing employment in their corresponding metropolitan areas.

${ }^{8}$ It is not unusual that the number of supply linkages exceeds the number of demand linkages. Because many sectors sell large amounts of their output to the final demand sector, they have relatively small proportions of their output available for interindustry transactions. Consequently, these sectors tend to have fewer demand than supply linkages.

${ }^{9}$ Since the sample includes an entire population, all manufacturing sectors in 57 of the largest metropolitan areas, any difference is statistically significant. However, it may be subjectively stated that the difference of 0.3 per cent is not very important.

${ }^{10}$ Edgar M. Hoover, The Location of Economic Activity (New York: McGrawHil1, Inc., 1948), p. 118 .

$11_{\text {See }}$ the appendix for sector classifications by resource usage.

12 For reasons mentioned in footnote 9, a significant difference could be ascertained without a statistical test. sector.

${ }^{13}$ The latter group of sectors may be considered linked to the final demand

\section{APPENDIX FOOTNOTE}

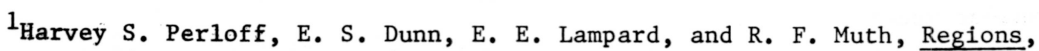
Resources, and Economic Growth (Baltimore: Johns Hopkins University Press, 1960), p. 680 . 